\title{
Antimicrobial-resistant Bacteria Arising from the Use of Colistin Sulfate in the Livestock (Antimicrobial-resistant Bacteria)
}

\author{
Summary
}

\author{
Food Safety Commission of Japan
}

The Food Safety Commission of Japan (FSCJ) conducted a risk assessment on antimicrobial-resistant bacteria arising from the use of colistin sulfate, which is used as a feed additive and veterinary medicinal products in the livestock. Both Salmonella and E. coli were considered as potential antimicrobial-resistant bacteria to be selected under the use of colistin sulfate in the livestock. As only limited reports were available on the colistin-resistance in Salmonella, FSCJ conducted a risk assessment focusing on $E$. coli as a hazard, on which the information was rather available. In the release assessment, the degree of possible selection of the hazard was evaluated as "Medium". Considering proper cooking of the livestock products, the degree of possible human exposure to the resistant bacteria via livestock products was evaluated as "Low". The degree of possible reduction or loss of clinical effectiveness was evaluated as "High" considering the current situation of colistin use in human medicine. From the above, the overall estimation of the risk was "Medium".

\section{Conclusion in Brief}

The Food Safety Commission of Japan (FSCJ) conducted a risk assessment on antimicrobial-resistant bacteria arising from the use of colistin sulfate, which is used as a feed additive and veterinary medicinal products in the livestock (cattle, swine and chickens,) according to the "Assessment Guideline for the Effect of Food on Human Health Regarding Antimicrobial-Resistant Bacteria Selected by Antimicrobial Use in Food Animals" (September 30, 2004) (Fig.1).

\section{Hazard Identification}

Colistin sulfate, a polypeptide antibiotic substance, has been used for the livestock in Japan since the 1950s. Colistin injection formula had been suspended in human clinical use due to the frequent adverse effects such as renal dysfunctions, as well as the development of substitute antibiotics.
In 2015, a colistin methanesulfonate formula for injections was re-approved owing to the situation where infections with multidrug-resistant gram-negative bacilli became clinical issues in recent years.

Two-component regulatory systems associated with chromosomal genes have been known as a mechanism of colistin-resistance in gram-negative bacteria. In 2015, Escherichia coli (E. coli) strains harboring a gene ( $m c r-1)$ associated with colistin resistance on plasmids were reported in China. The susceptibilities of E. coli and Salmonella strains against colistin in Japan remain high, being judged from the monitoring results of these bacteria sampled from the livestock between 2000 and 2015. Strains carrying the $m c r-1$ gene were, however, found among the samples.

Both Salmonella and E. coli were considered as potential antimicrobial-resistant bacteria to be selected under the use of colistin sulfate in the livestock. These resistant bacteria

Published online: 30 March 2017

This is an English translation of excerpts from the original full report (January 2017-FS/18/2017). Only original Japanese texts have legal effects.

The original full report is available in Japanese at http://www.fsc.go.jp/fsciis/attachedFile/download?retrievalId=kya03120816918\&fileId=201 Acknowledgement: FSCJ wishes to thank the members of Working Group on Antimicrobial-resistant Bacteria for the preparation of the original full report.

Suggested citation: Food Safety Commission of JAPAN. Antimicrobial-resistant bacteria arising from the use of colistin sulfate in the livestock: Summary. Food Safety. 2017; 5 (1): 24-28. doi:10.14252/foodsafetyfscj.2016033s 


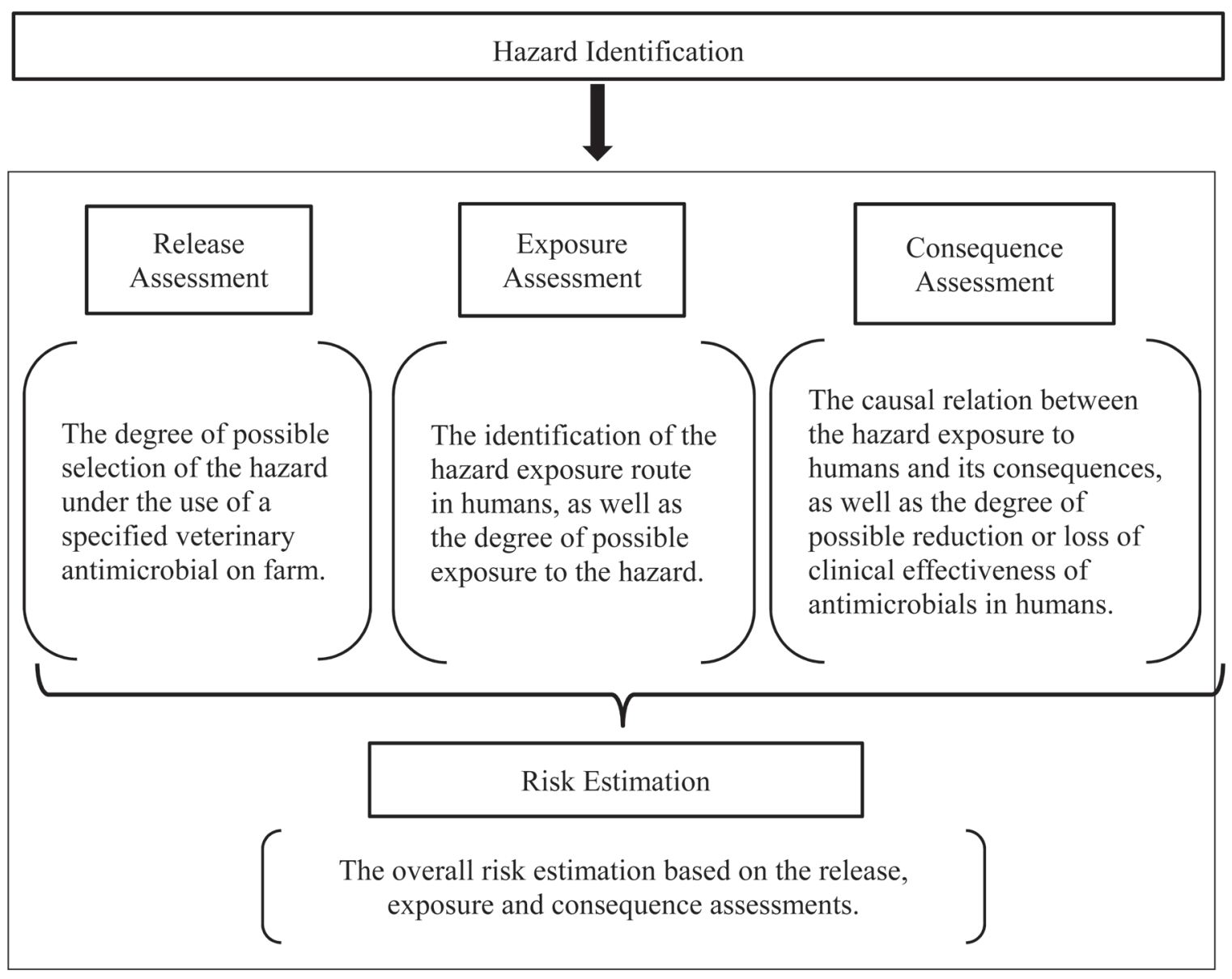

Fig. 1. Risk assessment procedure

may reduce or lose the effectiveness of clinical antibiotic treatment, in cases of occurrences of human infectious diseases due to the bacteria via livestock products, which are originated from cattle, swine and chickens. As only limited reports were available on the colistin-resistance in Salmonella, it was decided that the information on Salmonella was not enough to conduct a risk assessment at this point. FSCJ thus conducted a risk assessment focusing on E. coli as a hazard, on which the information was rather available.

\section{Release Assessment}

The release assessment discussed the degree of possible selection of the hazard, antimicrobial-resistant E. coli, arising from the use of colistin sulfate in the livestock. Japan first reported the detection of a $m c r-1$ positive $E$. coli isolate, which was sampled from diseased swine in 2007. Two percent of $E$. coli isolates from healthy livestock in 2015 carried the $m c r-1$ gene. Although the gene has been shown to be transferred among E. coli and other Enterobacteriaceae, many issues, such as fitness costs associated with its carriage, remain to be elucidated. Thus close attention needs to be paid to the trends of the amount of colistin use and genes associated with colistin resistance through continuous collection of relevant information. Considering the above, the degree of possible selection of the hazard was evaluated as "Medium" (Table 1).

\section{Exposure Assessment}

$E$. coli survives occasionally in meat, and thus human exposure to antimicrobial-resistant $E$. coli is possible via the livestock products. Colistin-resistant strains were, however, scarcely isolated from these products. Considering proper cooking of the livestock products, the degree of possible human exposure to the resistant bacteria via livestock products was evaluated as "Low" (Table 2).

\section{Consequence Assessment}

The degree of possible reduction or loss of clinical effectiveness was evaluated as "High" considering the current situation of colistin use in human medicine (Table 3).

\section{Risk Estimation}

The following possibilities were considered: 1) selection of the hazard arising from the use of colistin in the livestock as 
Table 1. Release assessment of the hazard (E. coli)

Assessment Outcome: "Medium"

\begin{tabular}{|l|l|l|}
\hline Relevant parameter & Concern \\
\hline 1) Emergence & "Moderate" \\
\cline { 2 - 3 } 2) Susceptibility & "Moderate" \\
\hline 3) Other concerns & "Moderate" \\
\hline
\end{tabular}

See reference.

Table 2. Exposure assessment of the hazard (E. coli)

\begin{tabular}{|l|l|l|}
\hline \multicolumn{2}{|l|}{ Assessment Outcome: "Low" } & Concern \\
\hline & Relevant parameter & "Moderate" \\
\cline { 2 - 3 } & 1) Biological properties & "Little" \\
\hline 2) Food contaminations & "Little" \\
\cline { 2 - 3 } & 3) Other concerns & \\
\hline
\end{tabular}

See reference

Table 3. Consequence assessment of the hazard (E. coli)

\begin{tabular}{|l|l|l|}
\hline \multicolumn{2}{|l|}{ Assessment Outcome: "High" } & Concern \\
\hline & Relevant parameter & "Great" \\
\hline 1) Importance in clinical use & "Moderate" \\
\cline { 2 - 3 } & 2) Severity of infectious diseases & "Great" \\
\cline { 2 - 3 } & 3) Other concerns &
\end{tabular}

See reference

Table 4. Outcome of overall risk estimation of the hazard (E. coli)

\begin{tabular}{|l|l|c|c|}
\hline \multicolumn{2}{|c|}{ Outcome of overall risk estimation: "Medium" } & Outcome of concern & Score \\
\hline \multirow{2}{*}{ Release assessment } & "Medium" & 2 \\
\cline { 2 - 4 } & Exposure assessment & "Low" "High" & 1 \\
\cline { 2 - 4 } & Consequence assessment & & 3 \\
\cline { 2 - 4 } & & & Total 6 \\
\hline
\end{tabular}

See reference

feed additive and veterinary medicinal products; 2) human exposure to the hazard via livestock products; 3 ) reduction or loss of clinical effectiveness of antimicrobials in humans. The overall estimation of the risk was "Medium" (Table 4).

Further information is necessary to understand the novel mechanisms of resistance conferred by the genes such as mcr- 1 and the significance, even in E. coli. Latest scientific findings and information are a key to future risk assessment. 


\section{Reference}

\section{1) Guidance for Release Assessment, Exposure Assessment and Consequence Assessment}

Based on the guideline for risk assessment, qualitative risk assessment on identified hazard(s) shall be conducted using the latest information on the release assessment, exposure assessment and consequence assessment. Risk assessment shall be conducted by considering comprehensively the concern levels for three relevant parameters according to criteria shown in Table 5.

\section{2) Guidance for Risk Estimation}

Based on the guideline for risk assessment, the risk of the hazard shall be cumulatively estimated based on the results of "release assessment", "exposure assessment" and "consequence assessment". Accordingly, the risk shall be estimated according to the sum of scores from the risk assessment components as shown in Table 6.

In cases extremely severe human diseases are expected or if any other relevant reasons exist, the overall risk may be estimated by raising the weight of the consequence assessment.

Table 5. Criteria and outcomes of release assessment, exposure assessment and consequence assessment

\begin{tabular}{|c|c|c|}
\hline Relevant parameters & Classification of concern & Outcome of Concern \\
\hline \multirow{4}{*}{$\begin{array}{l}\text { Release Assessment } \\
\text { 1) Are there any concerns about emergence of the hazard (eg, } \\
\text { mechanisms of acquired resistance, genetic information)? } \\
\text { 2) Are there any concerns about susceptibility distribution of } \\
\text { bacteria including the hazard? } \\
\text { 3) Are there any concerns about other factors (eg, pharmacokinet- } \\
\text { ics, usage, amount applied)? } \\
\text { Statements for the concern are classified as follows on each item } \\
\text { 1) 3): } \\
\text { The concern is "Great", "Moderate" or "Little". }\end{array}$} & $\begin{array}{l}\text { Two or more items assessed } \\
\text { as "Great". }\end{array}$ & $\begin{array}{l}\text { "High": The hazard* is selected } \\
\text { with high probability. }\end{array}$ \\
\hline & $\begin{array}{l}\text { Only one item assessed as } \\
\text { "Great", or two or more items } \\
\text { assessed as "Moderate". }\end{array}$ & $\begin{array}{l}\text { "Medium": The hazard is selected } \\
\text { with certain extents of probability. }\end{array}$ \\
\hline & $\begin{array}{l}\text { One item assessed as "Mod- } \\
\text { erate" and no item assessed } \\
\text { as "Great". }\end{array}$ & $\begin{array}{l}\text { "Low": The hazard is selected with } \\
\text { reduced extents of probability. }\end{array}$ \\
\hline & $\begin{array}{l}\text { Three items assessed as } \\
\text { "Little". }\end{array}$ & $\begin{array}{l}\text { "Negligible": The hazard is un- } \\
\text { likely to be selected. }\end{array}$ \\
\hline \multirow{4}{*}{$\begin{array}{l}\text { Exposure Assessment } \\
\text { 1) Are there any concerns about biological properties of bacteria } \\
\text { including the hazard (eg, survival, proliferation)? } \\
\text { 2) Are there any concerns about food contaminations with bacte- } \\
\text { ria including the hazard? } \\
\text { 3) Are there any concerns about other factors (eg, meat process- } \\
\text { ing process, marketing channels)? } \\
\text { Statements for the concern are classified as follows on each item } \\
\text { 1) 3): } \\
\text { The concern is "Great", "Moderate" or "Little". }\end{array}$} & $\begin{array}{l}\text { Two or more items assessed } \\
\text { as "Great". }\end{array}$ & $\begin{array}{l}\text { "High": Human exposure to the } \\
\text { hazard is highly probable. }\end{array}$ \\
\hline & $\begin{array}{l}\text { Only one item assessed as } \\
\text { "Great", or two or more items } \\
\text { assessed as "Moderate". }\end{array}$ & $\begin{array}{l}\text { "Medium": Human exposure to the } \\
\text { hazard is of certain probability. }\end{array}$ \\
\hline & $\begin{array}{l}\text { One item assessed as "Mod- } \\
\text { erate" and no item assessed } \\
\text { as "Great". }\end{array}$ & $\begin{array}{l}\text { "Low": Human exposure to the } \\
\text { hazard is of reduced probability. }\end{array}$ \\
\hline & $\begin{array}{l}\text { Three items assessed as } \\
\text { "Little". }\end{array}$ & $\begin{array}{l}\text { "Negligible": Human exposure to } \\
\text { the hazard is unlikely. }\end{array}$ \\
\hline $\begin{array}{l}\text { Consequence Assessment } \\
\text { 1) (a) Is the antimicrobial ranked as "I: Critically important as } \\
\text { human antimicrobials"? } \\
\text { (b) Is the antimicrobial a primary one for the human infectious } \\
\text { disease caused by bacteria including the hazard? } \\
\text { For item 1), statement for the concern is classified as follows: } \\
\text { The concern is "Great" if both (a) and (b) suffice, "Moderate" if } \\
\text { either (a) or (b) suffices, or "Little" if neither (a) nor (b) suffices. } \\
\text { 2) Are there any concerns about the severity and incidences of } \\
\text { human diseases caused by the hazard? } \\
\text { 3) Are there any concerns about other factors (eg, availability of } \\
\text { alternative drugs, status of antimicrobial resistance in hospitals)? } \\
\text { Statements for the concern are classified as follows on each item } \\
\text { 1) 3): } \\
\text { The concern is "Great", "Moderate" or "Little". }\end{array}$ & $\begin{array}{l}\text { Two or more items assessed } \\
\text { as "Great". }\end{array}$ & $\begin{array}{l}\text { "High": Reduction or loss of clini- } \\
\text { cal effectiveness to diseases caused } \\
\text { by the hazard is highly probable. }\end{array}$ \\
\hline
\end{tabular}

*ee Hazard" is antimicrobial-resistant bacteria arising from the use of antibiotic substances. 
Table 6. Risk estimation

\begin{tabular}{|c|c|c|c|}
\hline \multicolumn{3}{|c|}{ Outcome of the risk assessment components } & \multirow[b]{2}{*}{ Risk } \\
\hline $\begin{array}{c}\text { Release assessment (Score) } \\
\text { High (3) } \\
\text { Medium (2) } \\
\text { Low (1) } \\
\text { Negligible (0) }\end{array}$ & $\begin{array}{c}\text { Exposure assessment (Score) } \\
\text { High (3) } \\
\text { Medium (2) } \\
\text { Low (1) } \\
\text { Negligible (0) }\end{array}$ & $\begin{array}{c}\text { Consequence assessment (Score) } \\
\text { High (3) } \\
\text { Medium (2) } \\
\text { Low (1) } \\
\text { Negligible (0) }\end{array}$ & \\
\hline \multicolumn{3}{|c|}{ Sum of scores: $8-9$} & High \\
\hline \multicolumn{3}{|c|}{ Sum of scores: $5-7$} & Medium \\
\hline \multicolumn{3}{|c|}{ Sum of scores: $2-4$} & Low \\
\hline \multicolumn{3}{|c|}{ Sum of scores: $0-1$} & Negligible \\
\hline
\end{tabular}

